\title{
Journal of Technology and Science Education
}

\section{DESIGN AND ANALYSIS OF QUESTIONNAIRES FOR SURVEY SKILLS IN CHEMICAL ENGINEERING}

\author{
Susana Lucas Yagüe, Mónica Coca Sanz, Gerardo González Benito, Ángel Cartón López, Miguel Ángel Urueña \\ Alonso, Ma Teresa García Cubero \\ ${ }^{1}$ Departamento de Ingeniería Química y Tecnología del Medio Ambiente. \\ Universidad de Valladolid (España) \\ susana@iq.uva.es
}

\begin{abstract}
The new reorganization of university education has involved relevant changes in teaching and learning methodologies in order to help students to learn more effectively and to develop important skills and competences demanded by the professional world. In this sense the new configuration of the degree in Chemical Engineering required the identification of the main general and transferable skills, the implementation of the new teaching and learning strategies necessary to achieve them and, in addition, an evaluation procedure for determining the importance and the degree of development of a student's skills and competences.
\end{abstract}

In this exercise, two obligatory chemical reactor engineering subjects of the still in effect Chemical Engineering degree were chosen as examples of competence-based learning disciplines. For each one, a significant group of transferable and specific skills were selected to be developed. The identification and selection of skills was made according to the recommendations of the European Federation of Chemical Engineering (EFCE) together with the established requirements in the ministerial order for the new Chemical Engineering Degree (Ministerial order CIN/351/2009). In order to check the effectiveness of teaching strategies in helping students to acquire these abilities, specific questionnaires were designed. These tests allowed for the utility of the competences in question to be evaluated in terms of the students' professional work as future chemical engineering graduates and also facilitated the perception of skill development acquired through the methodology implemented in these subjects.

The results of the skill evaluation questionnaires revealed the importance that both university collectives (students and professors) give to the development of transferable skills. These skills included the ability to communicate effectively (including in English), to work in multidisciplinary teams and learn on one's own accord, and to be aware of the need for life-long learning. Furthermore, students and teachers agreed that there is a direct correlation between the higher development of specific skills and the chemical engineering learning outcomes. In this sense, an important effort should be devoted to the development of a students' transferable skills by way of modifying the current teaching-learning system (partial substitution of lectures with tutorials and seminars, strategies based on problem-solving, projects and case studies (individual or student team-work), use of internet and electronic tools, etc.).

Keywords - Transferable skills, Learning strategies, Competence evaluation, Chemical Engineering Degree.

\section{INTRODUCTION:}

When looking at the careers of Chemical and Process Engineers it can be observed that in an increasing number of countries, less than one quarter of the recent graduates work in conventional chemical and petroleum industries. The majority of the graduates find employment in a wide range of industries which have only very 
recently discovered the relevance of Chemical Engineering in their operations [1,2]. These new job descriptions, in addition to chemical engineering knowledge, require the development of general or transferable skills. Therefore, universities should place more emphasis on developing a student's transferable skills [3-7].

This innovation activity was carried out in chemical reactor engineering subjects of the still operational Chemical Engineering Degree. This degree, organized in a two cycle system $(3+2)$, has promoted different teaching and learning strategies and evaluation procedures based on competence acquisition according to the European Higher Education Space (EHES) philosophy [8-10]. In this sense, the organization of different subjects was focused on the modification of learning outcomes, the theoretical content, the main activities, the duration in credits (ECTS) as well as teaching and learning methodologies. These elements were aimed at helping students to learn more effectively and to develop important skills and competences required by the professional world.

The recommendations of the European Federation of Chemical Engineering (EFCE) for Chemical Engineering Education [11], the professional skills included in the ministerial order for the Chemical Engineering degree (Ministerial order CIN/351/2009, $9^{\text {th }}$ February) [12], as well as the most significant conclusions drawn from a University-Company meeting, were considered upon selecting the most relevant transferable and specific skills for chemical engineers at Bachelor level $[5,13]$.

In this paper, two obligatory chemical reactor engineering subjects of the still operational Chemical Engineering Degree, Applied Chemical Kinetics $\left(6^{\text {th }}\right.$ semester) and Chemical Reactors ( $7^{\text {th }}$ semester), were chosen as examples of competence-based learning disciplines. For each one a selection of transferable and specific skills, according to the above mentioned chemical engineering sources, were developed with programmed activities and subsequently evaluated. Specific questionnaires, completed by students and teachers, were designed to analyse the importance of transferable and specific skills in chemical reactor engineering education. Also assessed was the perception of how these acquired skills were developed via the methodology used in these subjects.

\section{OBJECTIVES}

The aim of this exercise was to analyse the importance and the level of competence acquisition attained in the subjects of Applied Chemical Kinetics (6th semester) and Chemical Reactors (7th semester).

In order to achieve these global objectives, different activities (oral presentations, written reports, complex problems solving) for both subjects were programmed into the curriculum in order to help students to develop certain kinds of transferable and specific skills. An evaluation procedure founded on competence-based questionnaires was designed to analyse the relevance of selected skills in chemical engineering education and the perception of the development of these skills in both subjects. Teachers and students alike who were involved in this educational exercise took part in the evaluation process.

\section{METHODOLOGY DESCRIPTION}

\subsection{Teaching and learning methodology}

Applied Chemical Kinetics is an obligatory subject corresponding to the $6^{\text {th }}$ semester of the Chemical Engineering Degree. The adapted educational programme of this discipline, as shown in the student guide, includes the general and specific learning outcomes connected with transferable and specific skills to be developed by students in this subject. Additionally, It outlines the distribution of contact hours (lectures, problem sessions, seminars, oral presentations, and intermediate learning outcomes tests), and other programmed activities such as technical visits, conferences, and tutorial sessions. This guide comes complete with information related to evaluation procedures as well as an estimation of the student workload required to achieve the aims of the programme (ECTS).

In this subject, students carry out four home assignments ( 2 individual and 2 group assignments). Individual home assignments consisted of the resolution of complex kinetic problems for which students were required to use appropriate computation tools. On the other hand, home assignments in group format were centred on 
the preparation of an oral presentation and a technical report of a topic relevant to the subject. The evaluation took into account the contribution of a final exam that comprised theoretical questions and problems $(70 \%)$ as well as the home assignments carried out throughout the course (30\%).

Chemical Reactors is a mandatory subject corresponding to the $7^{\text {th }}$ semester of the degree in Chemical Engineering. The structure and learning methodology of this discipline are similar to those of the subject described previously. Students have an educational guide that contains all the information and programmed activities for this subject. The study programme includes two partial examinations distributed in the semester, two individual homework assignments (chemical reactor problems), one group homework assignment (preparation of a written report), and a design project in conjunction with other disciplines (based on case study methodology). The evaluation takes into account all of these activities (partial examinations 15\%, home assignments $15 \%$, design project $15 \%$ ) and a final examination that includes theoretical and applied questions making up a weight of $55 \%$.

Bearing in mind the need to promote "active learning" founded on Internet technology, the previously proposed educational methodology for both disciplines was implemented by means of virtual courses using Moodle as an e-learning platform, in combination with conventional face-to-face sessions. These virtual courses are available at the website www.campusvirtual.uva.es.

The programmed activities of these subjects were not specifically designed for the acquisition of competences and transferable skills, although do facilitate their development. Problem sessions help students to develop their problem-solving capacity and the use of specific tools of resolution. The preparation of written reports and oral presentations improve the student's ability to communicate effectively in oral and written form. Lastly, the home assignments in team format provide an initial approximation to the knowledge, skill and ability requirements for teamwork. The specific learning outcomes can be improved with all the programmed activities.

\subsection{Skills evaluation questionnaires}

The learning methodology and programmed activities of both subjects were designed to help students to acquire not only the specific learning outcomes, but also transferable skills (manual, communication, leadership and organizational skills and thinking and problem-solving skills).

Specific competence-based tests (see Fig. 1 and Fig. 2) were designed for both disciplines to analyse the importance and level of acquisition of these abilities, skills or competences. Such tests were completed by the students and the teachers involved in these subjects.

The list of twelve skills included in the competence-based questionnaires was prepared according to the recommendations of the European Federation of Chemical Engineering (EFCE) for Chemical Engineering Education as part of the Bologna three cycle degree system. The questionnaires also adhered to the established requirements in the ministerial order for the new Chemical Engineering Degree (Ministerial order $\mathrm{CIN} / 351 / 2009,9^{\text {th }}$ February) and the most significant conclusions drawn from the University-Company meeting.

As shown in Fig. 1 and Fig. 2, these skills, abilities or competences were organized into two categories of learning outcomes for both subjects: From 1 to 7 (Applied Chemical Kinetics) and from 1 to 8 (Chemical Reactors), including the specific skills (directly connected to the knowledge outcomes of the discipline) and from 8 to 12 (Applied Chemical Kinetics) and from 9 to 12 (Chemical Reactors), the transferable skills are considered (other attributes or general abilities apply to all types of programme).

Each skill was evaluated using two different categories: the importance of the competence, ability or skill in relation with the students' future profession as Chemical Engineers and the level of skill acquisition attained via the subject curriculum. An evaluation scale from 1 (not at all) to 5 (very much) was applied. 


\section{SKILLS EVALUATION QUESTIONNAIRES}

\section{SUBJECT: Applied Chemical Kinetics (6 ${ }^{\text {th }}$ semester)}

Evaluate the following list of skills, selected for this specific su bject, in two different levels:

3. The importance of this competence, ability or skill in their future professional job as Chemical Engineer

4. The level of skills acquisition get with the program of this subject

Please, use the following scale:
1. Not at all 2. Very little
3. Somewhat
4. To a great extent
5. Very much

\begin{tabular}{|c|c|c|}
\hline SKILL/ ABILITY / COMPETENCE & Importance & $\begin{array}{l}\text { Acquisition } \\
\text { level }\end{array}$ \\
\hline $\begin{array}{l}\text { 1. Be able to use the knowledge of relevant basic sciences (mathematics, } \\
\text { chemistry, physics, molecular biology) and apply them to chemical } \\
\text { kinetics discipline }\end{array}$ & $\begin{array}{lllll}12 & 3 & 4 & 5\end{array}$ & 123345 \\
\hline $\begin{array}{l}\text { 2. Be able to plan and solve mass balances applied to continuous and } \\
\text { batch reaction systems }\end{array}$ & $\begin{array}{lllll}1 & 2 & 3 & 4 & 5\end{array}$ & 12345 \\
\hline $\begin{array}{l}\text { 3. Have an ability to select and apply different kinetic parameters } \\
\text { determination methods }\end{array}$ & $\begin{array}{lllll}12 & 3 & 4 & 5\end{array}$ & $\begin{array}{lllll}12 & 3 & 4 & 5\end{array}$ \\
\hline $\begin{array}{l}\text { 4. Be able to identify the most relevant industrial applications connected } \\
\text { with homogeneous and heterogeneous reaction systems }\end{array}$ & $\begin{array}{lllll}12 & 3 & 4 & 5\end{array}$ & $\begin{array}{lllll}12 & 3 & 4 & 5\end{array}$ \\
\hline $\begin{array}{l}\text { 5. Be able to plan, perform, explain and report simple experiments to } \\
\text { obtain kinetic parameters in continuous/discontinuous reaction systems }\end{array}$ & $\begin{array}{lllll}1 & 2 & 3 & 4 & 5\end{array}$ & 12345 \\
\hline $\begin{array}{l}\text { 6. Be able to apply phase transport models in order to describe the } \\
\text { behaviour of heterogeneous reactions }\end{array}$ & $\begin{array}{lllll}1 & 2 & 3 & 4 & 5\end{array}$ & 12345 \\
\hline $\begin{array}{l}\text { 7. Be able to identify the steps involved in reaction mechanism and } \\
\text { understand the limiting step concept }\end{array}$ & $\begin{array}{lllll}1 & 2 & 3 & 4 & 5\end{array}$ & $\begin{array}{lllll}1 & 2 & 3 & 4 & 5\end{array}$ \\
\hline 8. Be able to use appropriate computational tools & $\begin{array}{lllll}12 & 3 & 4 & 5\end{array}$ & $\begin{array}{lllll}12 & 3 & 4 & 5\end{array}$ \\
\hline 9. Have an ability to use technical literature and other information sources & $\begin{array}{lllll}1 & 2 & 3 & 4 & 5\end{array}$ & $\begin{array}{lllll}1 & 2 & 3 & 4 & 5\end{array}$ \\
\hline 10. Be able to work in multidisciplinary teams & $\begin{array}{lllll}12 & 3 & 4 & 5\end{array}$ & $\begin{array}{lllll}12 & 3 & 4 & 5\end{array}$ \\
\hline $\begin{array}{l}\text { 11. Be able to learn on his/her own, and have a recognition of the need for } \\
\text { life-longlearning }\end{array}$ & $\begin{array}{lllll}12 & 3 & 4 & 5\end{array}$ & $\begin{array}{lllll}12 & 3 & 4 & 5\end{array}$ \\
\hline $\begin{array}{l}\text { 12. Be able to communicate effectively, including in English, using modem } \\
\text { presentation tools as appropriate }\end{array}$ & $\begin{array}{lllll}1 & 2 & 3 & 4 & 5\end{array}$ & 12345 \\
\hline
\end{tabular}

Fig 1. Skill evaluation questionnaire of the Applied Chemical Kinetics subject. 


\section{SKILLS EVALUATION QUESTIONNAIRES}

\section{SUBJECT: Chemical Reactors ( $7^{\text {th }}$ semester)}

Evaluate the following list of skills, selected for this specific su bject, in two different levels:

1. The importance of this competence, ability or skill in their future professional job as Chemical Engineer

2. The level of skills acquisition get with the program of this subject

Please, use the following scale:
1. Not at all
2. Very little
3. Somewhat
4. To a great extent
5. Very much

\begin{tabular}{|c|c|c|}
\hline SKILL/ ABILITY / COMPETENCE & Importance & $\begin{array}{l}\text { Acquisition } \\
\text { level }\end{array}$ \\
\hline $\begin{array}{l}\text { 1. Be able to use the knowledge of relevant basic sciences (mathematics, } \\
\text { chemistry, physics, molecular biology) and apply them to analyse } \\
\text { chemical reaction systems }\end{array}$ & 12345 & $\begin{array}{lllll}1 & 2 & 3 & 4 & 5\end{array}$ \\
\hline 2. Understand the main concepts of chemical reaction discipline & $\begin{array}{lllll}1 & 2 & 3 & 4 & 5\end{array}$ & $\begin{array}{lllll}12 & 3 & 4 & 5\end{array}$ \\
\hline $\begin{array}{l}\text { 3. Be able to analyse, evaluate and compare relevant technical } \\
\text { altematives }\end{array}$ & 12345 & $\begin{array}{lllll}12 & 3 & 4 & 5\end{array}$ \\
\hline $\begin{array}{l}\text { 4. Be able to perform appropriate design reaction systems according to } \\
\text { codes of practice and industry standards }\end{array}$ & 12345 & $\begin{array}{lllll}1 & 2 & 3 & 4 & 5\end{array}$ \\
\hline $\begin{array}{l}\text { 5. Be able to apply quantitative methods and computer software relevant } \\
\text { in chemical reaction discipline }\end{array}$ & $123 \quad 3 \quad 5$ & $\begin{array}{lllll}12 & 3 & 4 & 5\end{array}$ \\
\hline $\begin{array}{l}\text { 6. Be able to apply optimization and design tools applied to reaction } \\
\text { systems }\end{array}$ & 12345 & $\begin{array}{lllll}12 & 3 & 4 & 5\end{array}$ \\
\hline $\begin{array}{l}\text { 7. Be able to plan and perform improvements in chemical reaction } \\
\text { systems }\end{array}$ & $123 \quad 45$ & $\begin{array}{lllll}12 & 3 & 4 & 5\end{array}$ \\
\hline 8. Have an ability to analyse complex chemical reaction problems & $123 \quad 3 \quad 5$ & $\begin{array}{lllll}1 & 2 & 3 & 4 & 5\end{array}$ \\
\hline 9. Be able to work in multidisciplinary teams & 12345 & $\begin{array}{lllll}1 & 2 & 3 & 4 & 5\end{array}$ \\
\hline $\begin{array}{l}\text { 10. Have an ability to use technical literature and other information } \\
\text { sources }\end{array}$ & $123 \quad 3 \quad 5$ & 123345 \\
\hline $\begin{array}{l}\text { 11. Be able to learn on his/her own, and have a recognition of the need for } \\
\text { life-longlearning }\end{array}$ & 12345 & 123345 \\
\hline $\begin{array}{l}\text { 12. Be able to communicate effectively, including in English, using modern } \\
\text { presentation tools as appropriate }\end{array}$ & $123 \quad 3 \quad 5$ & $\begin{array}{lllll}1 & 2 & 3 & 4 & 5\end{array}$ \\
\hline
\end{tabular}

Fig 2. Skill evaluation questionnaire of the Chemical Reactors subject.

\section{$4 \quad$ RESULTS}

The average results of the skills evaluation, extracted from the competence-based questionnaires, are summarized in Fig. 3 and Fig. 4. These tests, corresponding to the 2010/2011 academic course, were completed by teaching staff ( 2 teachers in each subject) and by students involved in both subjects: 50 students of the Applied Chemical Kinetics subject and 40 students of the Chemical Reactors subject participated in the survey.

Radial diagrams were selected as a suitable form to present the results of the skills evaluation. The radial diagram shows the ranking for each competence (the evaluation scale ranges from 0 to 5) of the two categories evaluated; importance and acquisition level. 


\section{(a) STUDENTS}

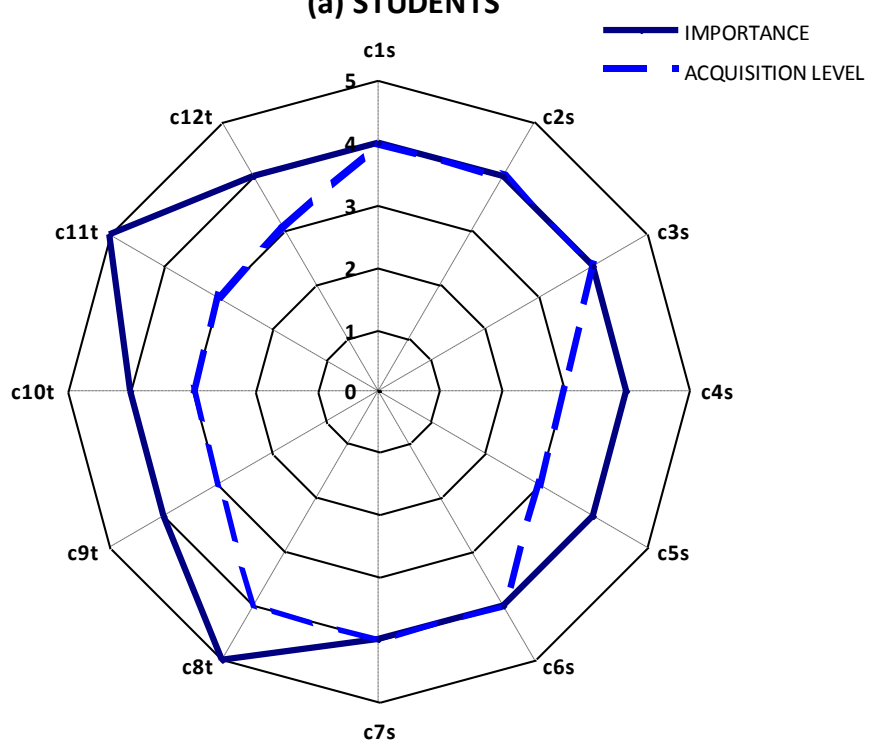

(b) TEACHERS

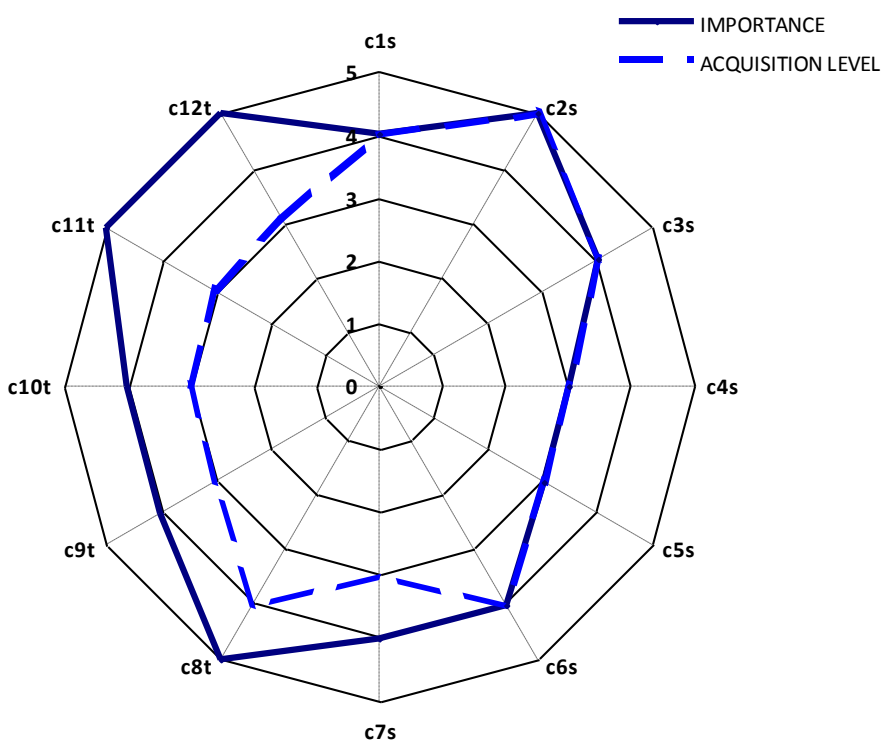

Fig 3. Results of the skill evaluation procedure for the Applied Chemical Kinetics subject (a) Students (b) Teachers.

Specific skills (c1s - c7s) Transferable skills: (c8t-c12t)

As can be observed in Fig. 3, the most important skills for students, both of the transferable skills, are the use of appropriate computational tools applied to the resolution of problems and the ability to learn on their own. Furthermore, teachers include, in addition to the previous skills, the capacity to communicate effectively, both in their native language as well as in English (transferable), and the ability to plan and solve mass balances applied to continuous and batch reaction systems (specific skill).

From a general standpoint, students and teachers gave more importance to general or transferable skills. On the other hand, they observed a greater level of skill development which was more directly related with knowledge acquisition (specific skills). This fact is corroborated by the results shown in the radial diagrams in which the importance of specific skills ( 1 to 7$)$ is evaluated with a similar ranking as the acquisition level acquired in the same subject (practically overlapped diagrams). In all the competences assessed, the importance for teachers and students alike was equal or higher than the acquisition level acquired. This fact revealed the need for continuous improvement in learning and teaching strategies to help students to acquire transferable skills. 
(a) STUDENTS

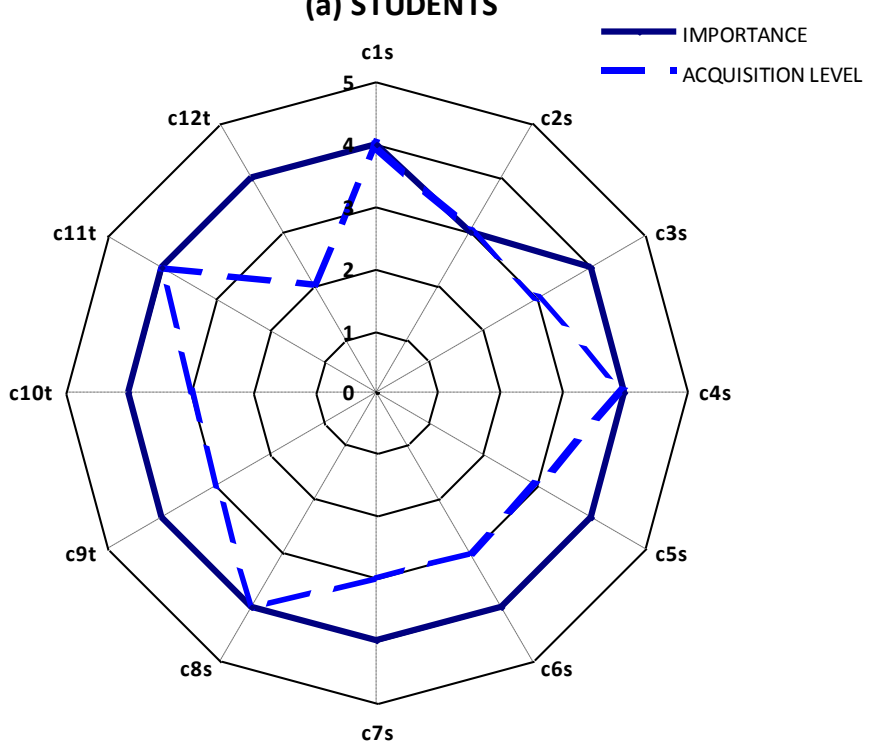

(b) TEACHERS

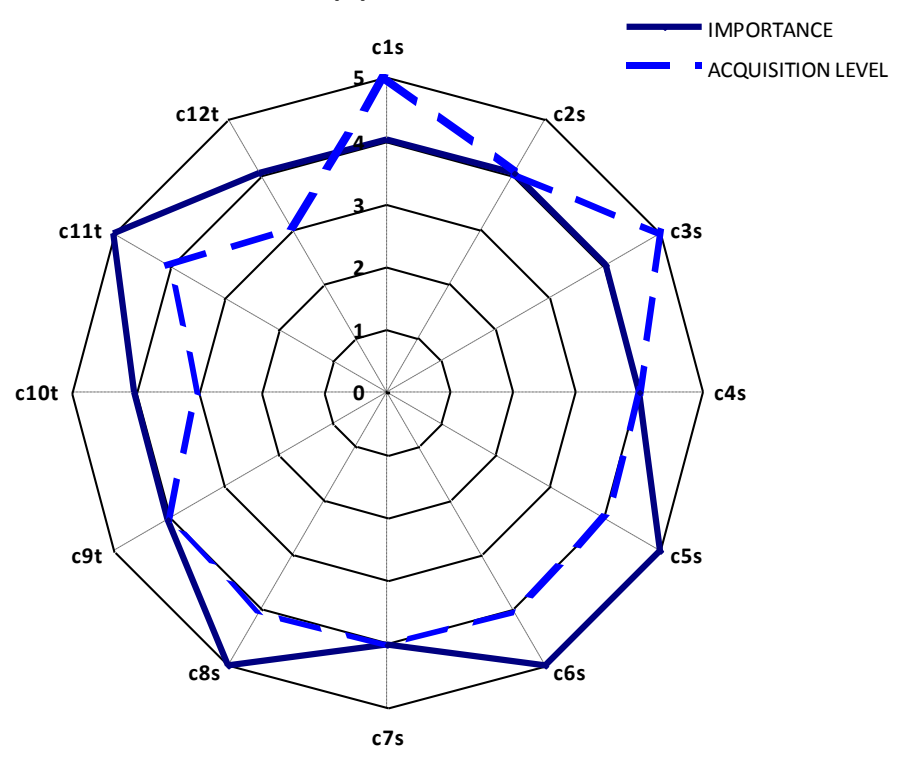

Fig 4. Results of skills evaluation procedure of Chemical Reactors (a) Students (b) Teachers.

Specific skills (c1s-c8s)Transferable skills: (c9t-c12t)

From the results shown in Fig. 4 of the skills questionnaires of Chemical Reactors subject, it can be concluded that students highly regard (a ranking of 4 of a maximum scale of 5) most transferable and specific skills. However, teachers appreciate even greater so, the student's ability to use the knowledge of relevant basic sciences and also analyse, evaluate and compare relevant technical alternatives (both specific skills). Likewise, the student's capacity to solve complex chemical reaction problem and the ability to learn on their own accord (both transferable skills) are also very highly considered.

In this case, students tended to give relatively more importance to those transferable skills required for their future professional careers, even though the relevant specific skills were developed to a higher level. Teachers attributed similar importance to transferable and specific skills but coincided with the students in terms of the higher development of knowledge outcomes of the discipline. As mentioned previously, teaching and learning strategies must be improved to help students harness the development of transferable skills. 


\section{CONCLUSIONS}

In this paper, two obligatory subjects of the still operational Chemical Engineering Degree, Applied Chemical Kinetics ( $6^{\text {th }}$ semester) and Chemical Reactors ( $7^{\text {th }}$ semester), were chosen as examples of competence-based learning disciplines. For each of these subjects, a selection of important transferable and specific skills were made according to the recommendations of EFCE, the established requirements of the Ministerial Order for the new Chemical Engineering Degree (Ministerial Order CIN/351/2009) and the most significant conclusions drawn from a University-Company meeting.

For both subjects, different activities were incorporated to help students to enhance the development of selected skills (problem sessions, team work-oriented seminars, oral presentations, written reports, partial examinations, etc.).

In order to check teachers' and students' perceptions of the importance and the level of development of transferable and specific skills in chemical reactor engineering subjects, competence-based questionnaires were designed. These competence tests have a double objective: to analyse the utility of such competences for professional work as future chemical engineering graduates, and to assess the level of skill development acquired with the methodology used in these subjects.

The results of the skill evaluation questionnaires, carried out by the teachers and students involved in this educational innovation, reveal the importance that the two university collectives give to the development of transferable skills. These skills are neither specific to the core nor to the degree level; however, they must be acquired to some extent during the first level of study and then addressed in further detail in the second. These skills include the ability to communicate effectively (including in English), to work in multidisciplinary teams, to exercise self-learning and recognise the need for life-long learning. Moreover, students and teachers agree that the higher development of specific skills is directly connected with chemical engineering learning outcomes (design reactor systems, planning and resolving of mass and energy balances applied to continuous and batch reaction systems, applications of different methods for kinetic parameter determination, etc.). In this sense, an important effort should be geared towards developing students' transferable skills. This could be accomplished by means of the modification of current teaching-learning systems such as the partial substitution of lectures with tutorials and seminars, homework based on problem solving, project or case study methodology (individual or team-work), oral presentation and written reports, use of e-learning platforms, etc.

\section{REFERENCES}

1 J. M. Prausnitz, Chemical Engineering and the post-modern world, Chemical Engineering Science, Vol 56, 2001, pp. 3627-3639.

2 A. Cartón López; M. T. García Cubero; G. González Benito; S. Lucas Yagüe; S. Bolado Rodríguez; P. A. García Encina and M. A. Urueña Alonso, Diseño de estrategias de enseñanza-aprendizaje para la adquisición de competencias en el título de Ingeniero Químico, III Jornadas de Intercambio de Experiencias de Innovación Docente de la Universidad de Valladolid, Valladolid, 2007.

3 D. C. Grant and B. R. Dickson, Personal skills in Chemical Engineering graduates. The development of skills within degree programmes to meet the needs of employers. Education for Chemical Engineers, Vol 1(1), 2006, pp. 23-29.

4 M. Marzo Navarro; M. Pedraja Iglesias and P. Rivera Torres, Las competencias profesionales demandadas por las empresas: el caso de los ingenieros, Revista de Educación, Vol 341, 2006, 643661.

5 S. Lucas; A. Cartón; M. T. García-Cubero; S. Bolado; P. A. García-Encina and G. González-Benito, El papel de la consulta externa en el diseño de los programas de Grado en Ingeniería Química, Simposio Internacional sobre Innovación y Evaluación de currículos en la formación de Ingenieros, Innovation and Assessment of Engineering Curricula, Valladolid, 2009, pp. 223-234. 
6 R. Pindado Rico; J. L. Lapaz Castillo; J. Marqués Calvo and J. Voltas i Aguilar, Una propuesta de evaluación de competencias genéricas en los estudios universitarios mediante pruebas graduadas orientadas al ejercicio de la profesión, VI Foro sobre la evaluación de la calidad de la Educación Superior y de la Investigación, Vigo, 2009, http://upcommons.upc.edu/eprints/bitstream/2117/6346/1/CO-261.pdf, [10th January 2011]

7 M. Morata; A. Pérez; F. Arrando; J. Fontana; V. Grau and E. Bartolomé, Elaboración de una rúbrica para la evaluación de competencias transversales en la asignatura de física, XIX Congreso Universitario de Innovación Educativa en las Enseñanzas Técnicas (CUIEET), Barcelona, 2011.

8 S. Lucas and M.T. García, V Jornadas de Redes de Investigación en Docencia Universitaria, Alicante, 2007, pp. 17, Estudio comparativo del nivel de desarrollo de competencias en asignaturas de carácter experimental y teórico en el Título de Ingeniero Químico,

9 M. T. García Cubero; S. Lucas Yagüe; S. Bolado Rodríguez; P. A. García Encina; G. González Benito and M. A. Urueña Alonso, Implementación de la metodología del estudio de caso en el título de ingeniero químico. Evaluación de competencias, II Jornadas Internacionales de Innovación Educativa, Zamora, 2007, pp. 126.

10 S. Lucas-Yagüe; M. T. García-Cubero; M. Coca-Sanz; G. González-Benito and A. Cartón-López, Identification of relevant transferable and specific skills in Chemical Engineering Bachelor, $8^{\text {th }}$ European Congress of Chemical Engineering, Berlín, 2011, ECCE 2011.

11 EFCE Bologna Recommendations for Chemical Engineering Education in a Bologna Three Cycle Degree System. Final Draft EFCE WP on Education, April 2005 Recommendations of EFCE WP chairmen considered, May 2005 Approved by EFCE Executive Board, July 2005, http://www.efce.info/Bologna_Recommendation, [Accessed 10 th February 2011]

12 Orden CIN/351/2009, de 9 de febrero, BOE de 20 de febrero de 2009, por la que se establecen los requisitos para la verificación de los títulos universitarios oficiales que habiliten para el ejercicio de la profesión de Ingeniero Técnico Industrial.

13 A. Cartón-López; S. Lucas-Yagüe; S. Bolado-Rodríguez; P. García-Encina; G. González-Benito; M. A. Urueña-Alonso; M. Coca-Sanz and M. T. García-Cubero, Competencias genéricas y específicas en el Título de Grado en Ingeniería Química, XVIII Congreso Universitario de Innovación Educativa en las Enseñanzas Técnicas (CUIEET), Santander, 2010.

Citation: S. Lucas, M Coca, G. González, A. Cartón, M. A. Urueña, M.T. García. Design and analysis of questionnaires for survey skills in chemical engineering, Journal of Technology and Science Education, JOTSE, Vol: 1 (2), 2011, pp 40-48. ISSN: 2013-6374; DOI: 10.3926/jotse.2011.25 